\title{
Growth Performance of Five Varieties of Soybean (Glycine Max. [L.] Merill) under Rainfed Condition in Bali Local Government Area of Taraba State-Nigeria.
}

\author{
${ }^{1}$ Talaka, A., ${ }^{2}$ Rajab, Y.S., ${ }^{3}$ Mustapha, A.B., \\ Department of Agricultural Technology, Federal Polytechnic, P.M.B. 05 Bali, Taraba State Nigeria.
}

\begin{abstract}
A field experiment was conducted at the Teaching and Research Farm of the Department of Agricultural Technology, Federal polytechnic, Bali, Taraba State to study the performance of five varieties of soybean (TGX 1951, TGX 1448-2E, TGX1740, TGX 1485-1D and TGX1904 under rain fed and soil conditions of Bali Local Government Area of Taraba State in northern guinea savanna zone of Nigeria. The experiment was arranged in split plot suited to completely randomized block design and was replicated three times in 2012 cropping season. Parameters measured at different growth stages include germination count at 3 days after sowing $(D A S)$, plant height at 6 and 8 weeks after sowing $(\mathrm{cm})$, number of leaves per plant at 6 and 8 weeks after sowing, number of branches per plant at 6 weeks after sowing and days to 50\% germination. The results showed that there were significant differences $(p=0.01)$ among the five varieties of soybean tested for germination count. Variety TGX 1448-2E had the highest germination count of 40.89 while the lowest germination count was observed for TGX 1951 (2.27). Significant difference was also observed for plant height at 6 weeks after sowing with TGX 1485-1D producing tallest plants $(41.67 \mathrm{~cm})$. Also, significant differences was observed on days to $50 \%$ germination $(p=0.01)$. Variety TGX 1904 had the highest value of 7.44. Other parameters such as plant height at 8 weeks after sowing, number of leaves/plant at 6 and 8 weeks after sowing, and number of branches per plant at 6 weeks after sowing were not significantly difference at $p=0.05$. The result of this study showed that there were variety differences among the varieties in response to soil conditions and agronomic practices under rain fed condition in northern guinea savanna zone of Nigeria. Varieties TGX 1448-2E and TGX 1904 performed better than other varieties tested. These varieties can be recommended and made available to the farmers in this area and also utilized for breeding program and seed multiplication to make it available for farmers.
\end{abstract}

Key Words: Soybean Varieties, Performance, Ecological Zone.

\section{Introduction}

Soybean (Glycine max [L.] Merr.) Is a member of the family papilionaceae (IITA, 1993). It is a herbaceous annual legume, usually erect, bushy and rather leafy which originated in China (Norman et al., 1995). The crop has relatively short growth duration due to its sensitivity to short day length in the tropics (Akparobi, 2009). It is a self-pollinated legume with natural out crossing of $<0.5$ to approximately $1 \%$ (Carlson and Lersten, 1987). Soybeans requires a free drain soil, sandy or medium loam soil, moderately fertile soils are particularly suitable (Tamiru et al., 2012). A ${ }_{\mathrm{P}} \mathrm{H}$ range of 5.5-6.0 and a temperature of $27^{0} \mathrm{c}-32^{0} \mathrm{c}$ are required by soybean for optimum growth. Rainfall of 500-750mm during the growing period is required (Adetiloye et al., 2000). Jackai et al., (1984) reported that soybean is frost sensitive; thrive best on sandy or clay loam and alluvial soils of good fertility and the optimum soil pH for soybean cultivation ranges from 6.0-6.5.

Soybean is widely distributed in most parts of the world; the crop has a lot of potentials in Africa (Adamu and Amatobi, 2001). It is generally known that the seed of soybean contains the highest and riches protein among all cultivated legumes (FAO, 1989). World-wide interest and attention in soybean is mainly due to its high nutritional value and seed protein content (Tiamigu and Idowu, 2001). It is primarily the source of vegetable oil and protein for use in food and industrial applications (Endress, 2001).

There have been many studies relating to the performance of soybean to environmental conditions, agronomic practices, variety performance. The bulk of soybeans produced in Nigeria come from the southern guinea savanna but production has also extended to the northern guinea savanna and forest belts (Okpara and Ibiam, 2000).

There are many varieties of soybean, which includes:

$>$ Medium Maturing Varieties (MMV) - TGX1479-2F, Samsoy-2, TGX1670-1F, TGX 1440-1E.

$>$ Early Maturing Varieties (EMV) - TGX1479-2F, TGX 1681-3F, TGX 10192 EB, TGX 1649-11F, TGX 1485-1D and TGX 1740-7F.

$>$ New Varieties (NV)- TGX 18055-F, TGX 923-2E, TGX 1740 and TGX 849-313D (Adetiyole et al., 2000). 
Until recently, farmers' attention in Bali Local Government had not been drawn to soybean cultivation. Because of that, there is inadequate information on the best yielding varieties of soybean in Bali Local Government Area. There is that need to find out among the varieties available the best yielding varieties suited for Bali Local Government Area and its environs within the same ecological zone.

In view of the above, five varieties of soybeans were grown on the Teaching and Research Farm of the Department of Agricultural Technology, Federal Polytechnic Bali, Taraba State, to determine the performance of the varieties in Bali Local Government Area and its environs and to recommend the best soybean variety for production.

\section{Materials And Methods}

Field experiment was conducted at the Teaching and Research Farm of the Department of Agricultural Technology, Federal Polytechnic, Bali, Taraba State in 2012 growing season. The study area is located within latitude $7^{0} 12^{\prime} \mathrm{N}$ to $9^{0} 00^{\prime} \mathrm{N}$ of the equator; and longitude $10^{\circ} 00^{\prime} \mathrm{E}$ to $12^{0} 00^{\prime} \mathrm{E}$ of the meridian (ATLAS, 2006). It has a land mass of about $10,000 \mathrm{~m}^{2}$ and lies within the guinea savanna ecological zone of Nigeria. The annual rainfall ranges from $750 \mathrm{~mm}$ to $1100 \mathrm{~mm}$. The temperature ranges between $22^{\circ} \mathrm{c}$ to $35^{\circ} \mathrm{c}$. The soil is dominantly of ferruginous tropical type that lies on sandy parent materials (Dada et al., 2006).

The land was ploughed using tractor and was harrowed using hoe. The experimental field was marked out into 9 main plots of $1.5 \mathrm{~m} \times 9.5 \mathrm{~m}$ including walk spaces and 45 sub-plots of $1.5 \mathrm{~m} \times 1.5 \mathrm{~m}$ each giving the total experimental site of $5.5 \mathrm{~m} \times 22.5 \mathrm{~m}$. The walk spaces were created between the main plots $(1 \mathrm{~m})$ and between sub-plots $(0.5 \mathrm{~m})$. The main plots treatment was soybean varieties (TGX 1951, TGX 1448-2E, TGX 1740, TGX 1485-1D and TGX 1904). The sub-plot treatments were beds raised at different levels.

The varieties of soybean used were obtained from Farming Skills Acquisition Center, Yola; Adamawa State. Seeds were sown on $29^{\text {th }}$ July, 2012 when rainfall was fully established. Seeds were drilled at inter-row spacing of $75 \mathrm{~cm}$ and intra-row spacing of $5 \mathrm{~cm}$ and later thinned to 2 plants per stand two weeks after sowing. The experimental design used was split plot in a randomized complete block design. The treatment was replicated three times. Mixture of pre-emergence herbicides of Butachlor and Glyphodiz was applied on the day of sowing to control weeds. NPK (15:15:15) was applied three weeks after sowing to boost early growth of the crop to suppress the weeds that will germinate later in the year during growing period.

Data collected includes: Germination percentage, Days to 50\% germination, plant bunch height at 6 and 8 weeks, number of leaves at 6 and 8 weeks after sowing. Data collected were subjected to analysis of variance (ANOVA) as described by Gomez and Gomez (1984). Means were separated using Duncans Multiple Range Test (DMRT) at 5\% level of probability.

\section{Results And Discussions}

The mean squares from the analysis of variance (ANOVA) for growth parameters of soybeans are presented in table 1 . The result showed highly significant difference at $p=0.01$ for germination count on varieties while sub treatment (beds) and interaction are not significantly difference at $p=0.05$ on germination count. In the same vein, the result showed significant difference at $p=0.01$ on number of days to $50 \%$ germination among the varieties. Table 1 showed significant difference at $p=0.01$ among varieties on plant height at 6 weeks after sowing while there was no significant difference on plant height at 8 weeks after sowing. This is due to the fact that after 6 weeks, the vegetative growth diminishes as reproductive stage set in. the differences in plant height agreed with earlier work carried out by Okpara and Ibiam (2000); Yusuf and Idowu (2000) who observed significant differences among soybean cultivars for plant height.

Other parameters measured such as number of leaves at 6 and 8 weeks after sowing and branches per plant at 6 and 8 weeks after sowing showed no significant differences at $p=0.05$. The result could be explained by the fact that even though number of branches was developed based on the genetic makeup of different varieties, it is generally accepted that many smaller leaves were produced during the branching stage as observed by Akparobi (2009).

The mean squares for sub treatment (beds) as well as that of interactions of varieties and beds showed no significant differences. These results could be due to the fact that the entire beds received similar treatments because emphasis was on the performance of the varieties, hence, the soils or beds did not exert any influence on the varieties.

The mean performance of growth parameters of soybeans measured in 2012 growing season are presented in Table 2. The result showed that variety 2 (TGX 1448-2E) gave the highest germination count of 40.89 followed by TGX 1485-1D which gave germination count of 40.78. TGX 1951 recorded the lowest germination count of 2.27. The findings disagree with the findings of Akparobi, (2009) who reported that TGX 1485-1D gave the lowest germination count of 55.42. Although, the varieties tested by Akparobi were different, only TGX 1485-1D was among the varieties tested. It could be that the varieties tested by Akparobi are performing better than TGX 1485-1D. In terms of beds, bed three performed better with germination count of 32.08. 
Table 2 showed mean performance of varieties on plant height at 6 and 8 weeks after sowing. The result showed that at 6 weeks after sowing, TGX 1485-1D produced tallest plants of 41.67 while at 8 weeks after sowing, TGX1904 produced the tallest plants of 61.10. The result showed that TGX 1904 responded much better to fertilizer application than the remaining varieties and that of TGX1485-1D that produces tallest plants at 6 weeks after sowing. Also, the result obtained by Adeniyan and Ayoola (2006) in Ibadan and Oniya showed that TX1448-2E gave the highest values for plant height from both locations in 2001 and 2002. This shows that varieties of soybeans responded differently in different locations and agronomic practices. In terms of beds, bed 3 produced tallest plants at 6 and 8 weeks after sowing of 35.55 and 60.50 respectively.

Mean performance of number of leaves at 6 and 8 weeks after sowing are presented in Table 2. At 6 weeks after sowing, TGX 1904 produced more number of leaves of 38.30 than other varieties while at 8 weeks after sowing, TGX 1740 produced more number of leaves of 97.60 . This shows that TGX 1740 responded positively to agronomic practices than other varieties. At six weeks after sowing, bed 2 produced more number of leaves while at 8 weeks bed 3 produced more number of leaves (96.60).

The mean performance of varieties on the number of branches per plant at 6 weeks after sowing indicated that TGX 1448-2E produced more number of branches (8.56) than other varieties followed by TGX1740 (8.11). The result confirm the findings of Adeniyan and Ayoola (2006) who reported that TGX 1448 2E produced the highest values of plant height in both locations (Ibadan and Oniya).

Table 2 showed mean performance of varieties on days to 50\% germination (7.44) while TGX 1740 and TGX 1485-1D gave the same days to 50\% germination (6.56). The result showed that the variation in germination of soybeans varieties is control by genetic and availability of moisture in the soil.

\title{
IV. Conclusion
}

In conclusion, the study showed that varieties TGX 1448-2E and TGX 1904 were consistently significantly higher for all the growth parameters measured when compared to other varieties, though the varieties exhibited delay in maturing. Best on the findings therefore, the two varieties have greater potentials of vegetative growth which leads to higher yields and are recommended for sowing in Bali Local Government Area and its environ in the same ecological zone.

Table 1. Mean squares from the analysis of variance for various growth parameters of soybean measured in 2012 growing season.

\begin{tabular}{|c|c|c|c|c|c|c|c|c|}
\hline \multirow{2}{*}{$\begin{array}{l}\text { Source of } \\
\text { Variation }\end{array}$} & \multicolumn{2}{|c|}{ DF GC } & \multicolumn{2}{|c|}{ Plant height $(\mathrm{cm})$} & \multicolumn{4}{|c|}{ No of leaves/plt. $\quad$ No. Branch/plt. D 50\%G } \\
\hline & & 3 DAS & 6WAS & 8WAS & 6WAS & 8WAS & 6WAS & \\
\hline Replication & 2 & 118.55 & 79.02 & 72.4 & 43.09 & 3708.7 & 1.089 & 6.956 \\
\hline Main Trt $(a$ & a) 4 & $2470.75^{* *}$ & * 517.41** & 391.4NS & $264.81 \mathrm{NS}$ & $674.0 \mathrm{NS}$ & $4.978 \mathrm{NS}$ & $82.978 * *$ \\
\hline Error (a) & 8 & 276.57 & 108.83 & 211.4 & 161.64 & 1667.6 & 6.728 & 20.011 \\
\hline Sub Trt (b) & 2 & $2.37 \mathrm{NS}$ & $28.16 \mathrm{NS}$ & $195.8 \mathrm{NS}$ & $162.29 \mathrm{NS}$ & $1072.4 \mathrm{NS}$ & $4.422 \mathrm{NS}$ & $0.689 \mathrm{NS}$ \\
\hline A X B & 8 & $35.62 \mathrm{NS}$ & $22.38 \mathrm{NS}$ & 197.2 & 156.01 & $668.3 \mathrm{NS}$ & $2.561 \mathrm{NS}$ & $3.494 \mathrm{NS}$ \\
\hline Error (b) & 20 & 28.54 & 20.23 & 158.4 & 95.50 & 801.5 & 1.867 & 2.867 \\
\hline Total & 44 & & & & & & & \\
\hline
\end{tabular}

Key
$\mathrm{DF}=$ Degree of freedom
$\mathrm{GC}=$ Germination count
WAS $=$ Weeks after sowing
DAS $=$ Days after sowing
Plt $=$ Plant

\author{
$\operatorname{Trt}=$ Treatment \\ NS $=$ Not significant \\ $* *=$ Highly significant \\ $\mathrm{D} 50 \% \mathrm{G}=$ Days to $50 \%$ germination
}

Table 2 Mean performance of growth parameters of soybean measured in 2012 growing season:

\begin{tabular}{|c|c|c|c|c|c|c|c|}
\hline \multirow{2}{*}{$\begin{array}{l}\text { Treatment C } \\
\text { A. Variety }\end{array}$} & \multicolumn{7}{|c|}{$\mathrm{G} /$ count Plant height $(\mathrm{cm})$ No of leaves/plt No of branches/plt $D$ to $50 \% \mathrm{C}$} \\
\hline & & & & & & & \\
\hline TGX 1951 & 2.27 & 21.67 & 45.0 & 26.0 & 85.4 & 6.78 & 0.00 \\
\hline TGX 1448-2 & 2E 40.89 & 37.11 & 58.8 & 29.6 & 77.6 & 8.56 & 6.33 \\
\hline TGX1740 & 38.78 & 36.56 & 59.2 & 36.4 & 97.6 & 8.11 & 6.56 \\
\hline TGX 1485-11 & ID 40.78 & 41.67 & 59.3 & 32.2 & 80.2 & 7.00 & 6.56 \\
\hline TGX 1904 & 35.56 & 36.22 & 61.1 & 38.3 & 94.1 & 7.67 & 7.44 \\
\hline Mean & 31.65 & 34.64 & 56.7 & 33.5 & 87.0 & 7.62 & 5.38 \\
\hline Prob. of F & 0.005 & 0.029 & 0.312 & 0.256 & 0.801 & 0.591 & 0.041 \\
\hline LSD & 18.078 & 11.340 & 15.81 & 13.82 & 44.39 & 2.820 & 4.863 \\
\hline
\end{tabular}




\begin{tabular}{|llllllll|}
\hline B. Beds & & & & & & & \\
1 & 31.29 & 33.07 & 53.3 & 29.8 & 80.7 & 7.00 & 5.47 \\
2 & 31.59 & 35.33 & 56.3 & 36.1 & 83.6 & 7.87 & 5.13 \\
3 & 32.08 & 35.53 & 60.5 & 34.7 & 96.6 & 8.00 & 5.53 \\
Mean & 31.65 & 34.64 & 56.7 & 33.5 & 87.0 & 7.62 & 5.38 \\
Prob. Of F & 0.921 & 0.272 & 0.312 & 0.208 & 0.285 & 0.119 & 0.789 \\
LSD & 4.069 & 3.426 & 9.59 & 7.44 & 21.56 & 1.041 & 1.290 \\
& $* *$ & $* *$ & NS & NS & NS & NS & $* *$ \\
\hline
\end{tabular}

KEY:

G/count $=$ germination count

Plt $=$ plant

WAS $=$ weeks after sowing

NS $=$ Not significant

LSD $=$ Least Significant Different

D $50 \%=$ Days to $50 \%$ flowering

** = highly significant

\section{References}

[1] Adamu, R.S. and Amatobi C.I., (2001). Field evaluation of soybeans genotypes for susceptibility to stinkbug damage at Samaru, Zaria, Tropical Oil Seed Journal, 7: 74-83.

[2] Adeniyan, O.N. and Ayoola, O.T. (2006). African Journal of Biotechnology, vol. 5(20), pp. 1886-1889.

[3] Adetiloye, P.O., Okeleye, K.A. and Tayo, T.O. (2000). Effects of seed innoculation with Bradyrhizobium japonicum on nodulation, growth and yield of soybean. In Tropical Oil Seeds Journal, 5: 22-29.

[4] Akparobi S.O. (2009), Middle-East Journal of Scientific Research, 4(1): IDOSI publications, 2009.

[5] Atlas, (2006). Macmillan Nigerian Secondary Atlas. Macmillan Nigerian Publishers LTD. Pp 22-25.

[6] Carlson, J.B.; and Lersten, N.R. (1987). Reproductive Morphology. In Wilcox J.R. (ed): Improvement, production and Uses (2 $2^{\text {nd }}$ ed; pp 95-134). Madison WI: American Society of Agronomy.

[7] Dada, F.O.A., Garba, M.J., Ijeoma, A. (2006). In Macmillan Nigeria Secondary Atlas. Macmillan Nigeria Publishers Ltd. ISBN 978978-081-355-4. Pp 22-25.

[8] Endress, J. (2001) - Product Characteristics Multinational Aspects and Utilization Campaign IL: AOCS Press.

[9] Food and Agricultural Organization (FAO), 1989. Soybean Production in the Tropics. Annual Report, pp: 14-16.

[10] Gomez, A.A. and Gomez K.A. (1984). Statistical procedure for Agricultural Research. Pp. 680.

[11] International Institute of Tropical Agriculture, IITA (1993). Achival Report (1988-1992), Crop Improvement Division, Grain Legume Improvement Program, part III. Soybean Biological Nitrogen Fixation. Pp: 10.

[12] Jackai, L.E.N., Dashiel K.E., Shannon D.A. and Root W.R., (1984). Soybean production and utilization in Sub-Saharan Africa. In: Proceedings world soybean research conference III. (R. Shibbes ed). Boulder Colorado, USA. PP: 1193-1202.

[13] Norman, M.J.T., Pearson, C.J. and Searle, P.G.E. (1995). Tropical Food Crops in their Environment. Second edition, Cambridge University Press.

[14] Okpara, D.A. and Ibiam, B. (2000). Evaluation of soybean to variety adaptability to a humid tropical environment in south-Eastern Nigeria. Journal of Sustainable Agriculture and Environment 2: 26-31.

[15] Tiamiru,S.; Lalit, M.P. and Tsige, A. (2012). Effects of Innoculation by Bradyrhizobium japonicum Strain on Nodulation, Nitrogen Fixation and Yield of Soybean (Glycine max \{L.\} Merill) Varieties on Nitisols of Bako, Western Ethiopia. International Scholarly Research Network. ISBN Agronomy. Pp. 1-8.

[16] Tiamigu, S.A.and Idowu, (2001). Economic of resource use among small scale soybean farmers in Niger state. Tropical Oil Seed Journal, 6: 71-75

[17] Yusuf, I.A. and Idowu, A.A. (2000). Evaluation of Four Soybean Varieties for Performance under different lime regimes on the acid soil of Uyo. Tropical Oil Seed Journal, 6: 65-70. 